International Journal of Linguistics, Literature and Translation (IJLLT)

ISSN: 2617-0299 (Online); ISSN: 2708-0099 (Print)

DOI: $10.32996 / \mathrm{ijllt}$

Journal Homepage: www.al-kindipublisher.com/index.php/ijllt

IJLLT

\title{
So Manga Pananaroon Sa Ranaw: Reflections of Meranaw Culture and Worldview
}

\author{
Mohammad Abdul Hamid Alawi Bantog (ID) $\square$ 1, Hasmina Domato Sarip-Macarambon (ID) 2 \\ ${ }^{7}$ Alumnus, English Department, College of Social Sciences and Humanities, Mindanao State University, Marawi City, Mindanao, \\ Philippines \\ ${ }^{2}$ Associate Professor, English Department, College of Social Sciences and Humanities, Mindanao State University, Marawi City, \\ Mindanao, Philippines \\ $\triangle$ Corresponding Author: Mohammad Abdul Hamid Alawi Bantog, E-mail: cobantog@gmail.com
}

\author{
ARTICLE INFORMATION \\ Received: December 19, 2020 \\ Accepted: February 08, 2021 \\ Volume: 4 \\ Issue: 2 \\ DOI: 10.32996/ijltt.2021.4.2.11
}

\section{KEYWORDS}

Proverbs, Meranaw, Pananaroon, Semiotics, Signs, Cultural

Semiotics, Intertextuality

\section{ABSTRACT}

This study was undertaken to analyze the Meranaw pananaroon and discover, through the signs incorporated in them, what they express and reveal of the Meranaw people's worldview, culture, and character. Sample pananaroons were classified and described according to context in the culture, that is, situations for which they are designed or meant to be used, based on appropriateness or fittingness and relevance. They were next subjected to semiotic and intertextual analysis, with cultural semiotics as the approach, focusing on how the signs are utilized for meaning-making, and what these reveal of the Meranaws as individuals and as a socio-cultural group. Focal concerns in the study were the Meranaw worldview, culture, and character. The study established that the pananaroon, the Meranaw word for the English proverb, adage, aphorism, and other gnomic sayings or utterances and homespun generalizations about life, are employed not only for rhetoric but purposes such as emphasis on a central message, conveyance of indirection and subtlety to avoid offense, allusion, self-deprecation or show of humility/self-effacement, irony, scorn (kapangilat), overstatement (hyperbole) and understatement. From the analyses of select pananaroon, through the lenses of the natural and cultural signs that conveyed them, the foundational ideals and overarching worldview that Meranaws value regardless of context and situation were also drawn: patience and prudence, avoidance of acting or deciding on impulse; belief in calculated boldness and arduous journeys; finding procrastination or vacillation as a fault; allowance and forgiveness for falling short of one's expectations; humility; awareness of one's station, revealing an ingrained and internalized class system; sensitivity, and; an overarching wish for clearness, harmony, order and peace (rinaw) in all things. The depths that the results this study reached not only strengthens semiotic analysis as a viable approach to proverb and linguistic/folklore studies, but also opens up new avenues or paths for fresh inquiry on Meranaw pananaroon, oral tradition, and folklore, and culture in general.

\section{Introduction}

"Ay timbang o Ranao

A di timbang o ragat"
"The weight of the Lake

is equal to the weight of the sea"

This proverb was found by the researcher among the pananaroon collected in the study of Hadji Asis' (1997), under the thematic category of Meranao proverbs expressing observations about life and human nature. The possible interpretations that could be drawn from its two, concise lines sparked in the researcher a slew of interesting, possibilities and questions that can be drawn from it. Most pressing in his mind was the use of the Meranaos' namesake, the Ranao, as a symbol; derived from which was the identity of the Meranaos (Disoma, 1999). That alone gave cultural weight to this pananaroon as, a reflection of the cultural, social,

K C AL-KINDI CENTER R D FOR RESEARCH AND DEVELOPMENT Your gateway to world-class research

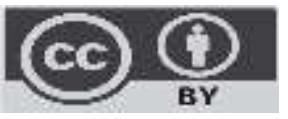

Published by Al-Kindi Center for Research and Development. Copyright (c) the author(s). This open access article is distributed under a Creative Commons Attribution (CC-BY) 4.0 license 
and economic importance of the Ranao (Lake) to the Meranaos, perhaps even meant to express how the Meranaos are tied to the Ranao; without the Ranao, there is no Meranao.

It must be said that these intepretations by the researcher were made in an armchair setting, through a literary approach, and such he is not confident with. In the sense that the researcher, though a Meranao by ethnicity, was not raised within the context, lifestyle, and environment in which Meranaos are; as such, not entirely privy to the vast slew of cultural, social codes that Meranaos brought up in their natural environment could draw from to form a more culturally relevant interpretation. This is important in the study of language traditions such as proverbs; for "the meanings of a particular language represent the culture of a particular social group" (Guessabi, 2017).

Thus, this study could be considered an etic study, of an outsider within his own culture, which to the researcher makes this inquiry far more important. It is one of the steps he is taking to attune himself to his own culture, which he believes is not a necessary step exclusive to Meranaos like him who are raised apart from their culture.

The pananaroon, or proverb, is an important part of the Meranaos' oral tradition, and embodies their perceived cultural, religious, and social values, beliefs, and traditions. As is tradition, they are recited in weddings, coronations and enthronements, and even in conflict resolutions, especially by those highly revered as orators, or are well versed in katharo sa lalag (oratory speech) (Hadji Asis, 1993; Dipatuan \& Sangcopan, 2012). Disoma (1990) asserts that their pananaroon are taken from the Meranaos' experiences and aspirations, and has been, and will continue, to be spoken in distinct events of Meranao life.

With the advent of social change, education, modernization, and acculturation, the interests of the Meranao in promoting and preserving this and other parts of their oral tradition is declining (Sarangani, 2010). Already this can be felt throughout the region and among Meranaos; ceremonies where these traditions were once revered are giving less to no promotion of these traditions, or are changing them to suit a modern form, such as with the rina-rinaw, a modern form of the traditional bayok (Meranao folk song), but with musical accompaniment.

This tide of disinterest is what the researcher wishes not to ride, in his wish to learn about an enduring legacy of Meranao culture through another study that would give focus to the richness of the pananaroon (proverb) as a reflection of Meranao culture. This is in his belief in the words of Aremu (2015) in his study, who asserts that proverbs remain a powerful medium to hold and transmit from generation to generation the culture, philosophy, social morality, values, and sensibility of a people, and Disoma (1990), who regards it as expressions of truths about the Meranaos' moral actions, cultural practices, religious convictions, political and social ideologies, socio-linguistic situations and existential projections.

Nevertheless, where studies by fellow Meranaos such as Hadji Asis (1997), Dimaporo (2016), and Dipatuan \& Sangcopan, (2012) rest, the researcher wishes to diverge from. He notes how their studies were focused in revealing the structure and themes of the pananaroon as a way to gain a general perspective of the Meranaos through them. The researcher seeks another way into these pananaroons: the signs.

Signs, as cultural semioticians argue, and the sign systems they work in, are not merely instrumental to culture; they constitute it (Cassirer, 1923). They are present in aspects of culture, as both linguistic and non-linguistic signs. Naturally, this means they are also present in the proverbs; in fact, proverbs are considered sign systems themselves, whose significations of symbolisms make them a significant aspect of language (Daramola, 2013), and as such their meanings and messages reveal much of the people they are from (Daramola, 2013; Aremu, 2015). Some linguists identify them as metaphors in the semiotic sense, and others as indexes or icons of their culture (Esimaje et al., 2014); as such, semiotics and semiotic analysis is considered a natural intertwinement with proverbs in folklore studies. As Russian folklorist and semiotician Pëtr G. Bogatyrëy (1971) once expressed, "the investigation of proverbs in their semiotic aspect is one of the most grateful tasks of a folklorist" (Bogatyrëv, 1971; Grzybek, 2014). So it is with the researcher, for the pananaroon is considered the cradle of the Meranao culture, attitude, and beliefs, as proverbs are to all other cultures; and signs, which include images, and symbols, used in the pananaroons of the Meranao are seen to be a component of these which are effective in reflecting unique cultural and social aspects and patterns of the Meranao. As such, he deems this approach an interesting and understated endeavor, and to him a rich and worthwhile direction in reaching for the dept the pananaroon; and through it, his fellow Meranao.

In this study, the researcher intended to conduct an in-depth analysis of the occurrence and use of signs -- images, allusions, and symbols -- found in collected pananaroons of the Meranaw with the end in view of illuminating or bringing to light dominant, significant and enduring aspects and patterns of the Meranaw worldview, culture, and character. To focus the study on its object, the following questions are formulated to frame the inquiry: 1) What is the pananaroon, and what are the contexts and uses of the 
pananaroon? 2) What are the common signs used in the pananaroon? 3)How were these signs incorporated into or used in the pananaroon? 4) What do the occurrence and use of these symbols and images in the pananaroon reveal of the Meranaw worldview, culture, and character?

\section{Literature Review \\ Proverbs}

Ahmad Rehzai, in his paper Rhetorical function of proverbs based on literary genre, summarizes definitions from Cuddon (1984), Mieder (2004), and Akbarian (2010) and, to reconcile their definitions, sums them up through attributes of the concept that is the proverb: 1) A short pithy saying which embodies a general truth; 2) Related in form and content to the maxim and the aphorism; 3) Proverb based on common sense or the practical experience of humanity; 4) Proverb is handed down from generation to generation; 5) They are used to carry more weight in a discussion, thus with them a weak person is able to enlist the tradition of the ancestors to support his position, or even to argue a legal case, and; 6) Unlike idioms or other formulaic types, shortened versions of the complete sentence form of some proverbs may be offered.

To these attributes, Rezaei adds what to him is a less considered characteristic by other definitions: that is, the quality of the message transmitted from sender to receiver or addressee, should be clear and without ambiguity, which to him accounts for the ability of any reader to understand a proverb of another culture. For the Filipinos, the proverb is considered as an original literary tradition, and a significant unifying force in their communities (Dipatuan \& Sangcopan, 2012).

Eugenio (1987) as cited by Dipatuan \& Sangcopan (2012), quotes Taylor (1950) in her book, a collection of Philippine Folk Lore Proverbs with a far briefer and succinct definition of proverbs: "a terse didactic statement that is current in tradition, or, as an epigram says, 'the wisdom of many and the wit of one'. It ordinarily suggests a course of action, or passes judgment in a situation." She noted in her book that Philippine proverbs can encompass other forms of folk speech related to the proverb. But more important was her assertion that proverbs are an integral part of the Filipino cultural heritage, and should thus be cherished and treasured, for Filipinos to be guided in charting their future.

Eugenio (1987) then takes a step forward and outlined a classification of proverbs according to their subject matter: 1) Proverbs expressing a general attitude towards life and the laws that govern life (Ang kapalaran ko di ko man hanapin, dudulog lalapit kung talagang akin), 2) Ethical proverbs recommending certain virtues and condemning certain vices (Walang utang na di pinagbayaran), 3) Proverbs expressing a system of values (It takes only a moment to squander what took a year to save), 4) Proverbs expressing general truths and observations about life and human nature (Huli man at magaling, ay naihahabol din), Humorous proverbs (Kay tagal nanindahan, kabili-bili'y balindang), and 5) Miscellaneous proverbs, typically expressive of specific realities to a certain area (It is better to go home and weave a net than to stay on the shore and watch the fish).

As to the generation of proverbs, Eugenio again cites Taylor (1950) on the different ways proverbs may arise: from simple maxims and aphorisms, already existing proverbs, the condensed idea/theme of a story or fable, and, which Eugenio (1987) defined as constituting the most significant and distinctive group of Philippine proverbs, that is, those that arise from the symbolic or metaphoric use of an incident. She details here that these are the proverbs that are generated from the folk and their daily life reconstructing the comprehensive life of the Filipino, including Meranaws. After all, as Aremu (2015) also points out, proverbs remain a powerful medium to hold and transmit from generation to generation the culture, philosophy, social morality, values, and sensibility of a people. Of course, as Eugenio detailed, the need to consider the environmental/incidental context from which proverbs arise and are used is necessary to truly perceive the realities contained in these proverbs.

\section{Semiotic Analysis and Proverbs}

It is known that language is a medium of culture. Guessabi (2017) states its importance to culture succinctly: "the meanings of a particular language represent the culture of a particular social group". Semiotics being the study of meaning in texts stemming from sign relationships, it is undeniable that it is a viable approach to the study of language - language being the most significant analytical paradigm and code for all other sign systems (Danesi, 2004; Innis, 1985; Daramola, 2013). For though the study of language meaning has been the center of numerous approaches, semiotics explores an interesting, more extensive level of language meaning, involving non-linguistic, verbal and non-verbal signs (Umar, 2017). It fits as well the role of language in culture; semiotics, after all, "encompasses the whole of cultural life", according to Eco (1985).

After detailing the progress which the discipline has undergone, Berger (2004) summarizes in his book the core concepts of modern semiotics: the focus of semiotics is the signs found in texts. Signs are understood to be combinations of signifiers and signifieds; Because nothing has meaning in itself, the relationships that exist among signs are crucial. An analogy can be made 
with words and grammar: It is the ways in which words are combined that determine what they mean. Language is a social institution that tells how words are to be used; speaking is an individual act based on language; Texts can be viewed as being similar to speech and as implying grammars or languages that make the texts meaningful. Codes and conventions (context) make the signs in a narrative understandable and also shape the actions (Berger, 2004).

As to where semiotic analysis best intersects with language, Daramola (2013) was explicit: proverbs. The reason why being the significations of the symbolisms present in proverbs, which, as reflections of its corresponding peoples' "experience of life, human relationship and interaction with the world of nature", usually reflected through symbolism and metaphors (Akporobaro \& Emovon, 1994; Daramola, 2013). In fact, proverbs are considered metaphors by linguists, as it fits the definitions they set for it. It then is a rich research object for semiotic analysis, to analyze the meanings and messages of proverbs through its significations, mutual context, and what it reveals of its people (Daramola, 2013; Aremu, 2015).

Gryzbek (2014), recognises that semiotics and proverbs have long had little serious, institutionalised academic study outside the field of folklore, where both are highly regarded; both have been recognised only as methodological tools by other disciplines and sciences (Taylor, 1931). But, attributing it to the rise of structuralist approaches, he maintained that the semiotic approach to proverbs have increased in trend, becoming a "research desideratum". Gryzbek (2014) then outlines the three dimensions now taken up in semiotic analysis, which could be applicable to proverbs: pragmatics is concerned with the relation between sign and sign users, syntactics is directed towards the formal relations of signs to one another, and semantics concentrates on the relations of signs to the objects to which the signs are applicable. Furthermore, he enumerates the possible models and concepts of semiotic analysis that are adopted for interpreting proverbs: Holistic vs. Componential Analysis, Analytical vs. Synthetic Clichés, Logics and Analogics, Proverb Semantics to Semantic Proverb Classification, paramiology, and the semiotics of culture.

Ernst Cassirer (1923) was the proponent of funneling or focusing semiotic analysis on culture, and laid its foundation and role as a subdiscipline of semiotics. According to him, certain kinds of sign systems called the "symbolic forms" of a society also constitute its culture. With this, he coined the term "cultural semiotics", and assigned to it two tasks: a) the study of sign systems in a culture with respect to what they contribute to the culture, and b) the study of cultures as sign systems with respect to the advantages and disadvantages which an individual experiences in belonging to a specific culture.

Along these lines, Posner (2004) ascribed that can only be answered by the theoretical framework of cultural semiotics: a) How do the signs, sign processes, and sign systems of a culture differ from non-cultural (i.e. natural) signs, sign processes, and sign systems? b) how do the interpreters of cultural signs differ from those of natural signs? c) what determines the identity and boundaries of a culture? d) what relations do different cultures have to each other within the semiosphere? and e) how does cultural change originate?

\section{The Meranaw and their Oral Tradition}

The Meranaw are a cultural minority group of the Philippines, inhabiting the provinces of Lanao del Sur and Lanao del Norte, although some of them are also found in some provinces and big cities in the Philippines; the latter a result of migration and diaspora for economic reasons. Being one of the most conservative Muslim groups in the country, they have successfully maintained their rich culture up to the present day, even with the influx of modernization (Disoma (1999); Ulla, 2014). Highly ethnocentric and proud of their roots, Maranaws are considered courageous and zealous in protecting and preserving their values and traditions (Fardejah, 2017; Cimene et al., 2019). They are the largest Moro and Muslim cultural minority in the Philippines. Generally, Meranaws are Muslims. In the Philippines, they are regarded as the most traditional Muslims resistant to changes and defensive of their culture (Gowing, cited in Madale and Cheng 1994).

The Meranaw people reside mainly in Lanao (Ranao) from which the ethnic identity "Meranao" (Meranaw) or "M'ranao" is derived. There has long been a misconception with how their name is written and pronounced, as many refer to them as 'Maranao'. A renowned Meranaw poet Datu Tingcap G. Pandi has his version of the etymology of the appellation. He said that the word "Meranaw" is a compound word composed of "mera" which means "peacock" and "naw" which means "awake". In other words, "meranaw" means "an awake peacock" (in Goling-Pantao, 2018). The more popular etymological explanation traces the origin of the word to the legend-rich Lake (Ranao). The term is very meaningful in the Meranaw language; as it means "people of the lake" (Disoma, 1999; Ulla, 2014).

According to Dimaporo (2016), the value system of the Meranaw is deeply rooted in their maratabat -- a socio-psychological force that encompasses their pride, honor, self-esteem, shame, face, rank, and social status -- and kinship. From the adherence and protection of the maratabat comes much of the core values of Meranaws: solidarity with their family and clan, utmost respect 
for elders and higher ranked individuals, modesty in women, carefulness in speech, respect, and love. Failure to follow through with any of these values can constitute shame (kaya), and any offense that may challenge or demean an individual may lead to blood feuds (rido), to defend ones' maratabat. These values are practiced alongside the major religion of the Meranaw, Islam, from which the Meranaw also draw much of their values and way of life.

As Velasco (2017) citing Laubach in Madale (1966), reiterates, the richness of Meranaw literature draws amazement, as it is remarkable that, since it is just beginning to be recorded, the Meranao were able to hold on to their literature in their memories alone. Their literature, oral in nature, manifests most prominently through their ancient epic song, the Darangen, but also through folk stories and legends (Agamaniyog), folk songs and poems, idiomatic expressions, proverbs (pananaroon), genealogy (salsila), etc. This faithful preservation, persisting generation after generation, can be attributed to the preservation and continued use of their language even in the present day. As stated in Lobel and Riwarung (2012),

"In terms of sociolinguistics and language attitudes, the Maranao language (and culture) is likely one of the least endangered in the Philippines. The Maranao are one of the few Philippine ethnolinguistic groups who in the twentyfirst century still resolutely maintain use of their language and wear traditional clothing, even in Manila and other large cities."

Language being the vehicle for the transmission of cultural knowledge (Hooft, 2009), and as asserted by Bolinger (1980), it is not difficult to trace how the Meranaw oral tradition has persisted throughout the years. Earlier studies that sought to 'conscienticize' the community or the race itself about the need for preservation and transmission efforts include Sharief's The Meranaw Kandaonga as Ritual Speech and Verbal Art (2008) and Sarangani's (2010) work on the rina-rinaw and banda. Sarangani (2010) described the present as "an age of ruptures or discontinuities and liquidations" which have not spared Meranaw oral traditions -- e.g. totol, pananaroon, antoka, bayok, katharo sa lalag. The clarion call for the preservation of these traditions was sounded again, with a sense of greater urgency by Hasmina D. Sarip and Alyanah G. Pantao in their works on the evolution/preservation of the bayok in the rina-rinaw and the katharo sa lalag as a living tradition among the Meranaws, respectively.

As found by Sarip (2018) through her dissertation on the rina-rinaw, though the Meranaw's oral traditions, especially their literary heritage, are still fragile and vulnerable to change in the face of globalization and foreign/modern popular art forms enjoying a vogue among Meranaw youths, these have not been eroded entirely; the bayok, tubad-tubad, and other verbal arts are still commissioned and performed in gatherings, and kapamlalag, or katharo sa lalag, oratory speeches, are employed in conflict resolution and weddings, often studded with Meranaw euphemisms and idiomatic expressions (Guro, 2008), and dramatically concluded with appropriate pananaroons (proverbs), is of itself a rich system with usage in all aspects of social intercourse (Dimaporo, 2016).

This oral tradition and literature is said to reflect the Meranaw values, customs and perception of reality (Hadji Asis, 1993; Ulla, 2014), and thus has been shown to reveal much about the identity of the Meranaw people. Madale, in Dimaporo (2016), states that understanding Meranaw literature leads to further understanding of Meranaw society. Numerous studies have been made focusing on these mediums in their exploration of the Meranaw. In a descriptive literary study on Meranaw folk songs by Velasco (2017), she finds that these folk songs are "... rich in imagery and symbolisms and deal with themes that the Maranao confront in their everyday lives (love, courtship, marriage) or consider vital to the survival of their culture and identity as a people (good manners, social behavior, cultural attitudes and values)." She then asserts that this oral tradition "enables the Maranao to express their worldview and, at the same time, demonstrates their cultural uniqueness."

In another study, on Meranao folktales, Reyes, Abdulmalic and Matanog (2012) describe the view and role of women in Meranao society through Meranao folktales. They state the importance of understanding a society through its reflective literature, citing Macaraya (1993): "Maranaos' mental set, attitude, models they take as their own in life, their behavior, action and reaction, their decision-making process are largely influenced by culture which includes language and literature."

\section{The Meranao Pananaroon}

The pananaroon (proverb) of the Meranaw is part of their oral literature and tradition, and incorporates and reflects their values, customs, beliefs, behaviors, traditions, and way of life. It is said that it is in their pananaroon where their perception of reality manifests. By tradition, they are usually recited in courtship (kandaonga), weddings (kamkawinga), the coronation of a sultan (kasolotan), exchange of verses (kasambonga sa lalag) and other social and traditional activities, events, and rituals (Hadji Asis, 1993; Dipatuan \& Sangcopan, 2012). The pananaroon can also be a form of expression where views on restrictions and taboos can be expressed (Dimaporo, 2016), which reflects the highly euphemistic, polite, even sensitive speech expected of the Meranao as a 
bilangataw (Guro, 2008). In following this, Dimaporo also explains that the pananaroon is indirect and metaphorical in nature, to guard against possible offense to any Meranao which is tantamount to an offense to that Meranaw's entire family, and even ridu. Guro cited that this can be summed up in a pananaroon:

Ino ako den toman a roroyoden ko so ig na pagi-iingatang ko bo ka bapiya mabinandar na asar a pimbikitan. (I take precautions so that whatever the outcome may be, at least l've done my best in preventing bad outcome).

Dimaporo (2016), in her study's findings, also made mention of the dominant moral themes in the pananaroon: kababaya (love), kaya (shame), and kathathabanga (solidarity). Disoma (1999) in Dimaporo (2016) centers on the pananaroon as expressions of truths about the Meranaos' moral actions, cultural practices, religious convictions, political and social ideologies, socio-linguistic situations and existential projections. Disoma (1999) asserts that their pananaroon are taken from the Meranaws' experiences and aspirations, and has been, and will continue, to be spoken in distinct events of Meranaw life. Hadji Asis concedes this longevity and purity of the pananaroon in the face of modernization, owed to the continuing high valuation of traditional Meranaw culture, particularly folklore which forms part of the rich legacy transmitted by their ancestors and the preservation effort mentioned earlier in this study. This makes the analysis of the pananaroon a valid path to the understanding of the Meranaw people, identity, and values.

Preservation of said heritage is, however, an uphill struggle, as winds of change swirl about culture (Bailey \& Peoples, 1999; Dipatuan \& Sangcopan, 2012). Like all other non-mainstream cultures, Meranaow culture is not invulnerable to the threat of endangerment and even consignment to oblivion, the; limbo of forgotten things. In fact, researchers agree that factors such as education (Ananggo, 2000), interest in foreign media and culture through globalization (Sarip, 2018), and changes in fashion, taste and practices (Sarangani, 2010), may eventually lead to a decline in the interest and use of the Meranaos' oral tradition, as they have become acculturated.

\section{Methodology}

For this study, the researcher adopted a qualitative-ethnographic and analytical design considering the nature of the inquiry, which entails collecting samples of pananaroon and relevant information about these, and gathering from the field information, classifications, and interpretations about these pananaroons, for analysis. Thirty sample specimens were taken from Hadji Asis' (1997) study on the pananaroon, and from the book Paninggalan sa Ranao, compiled by Macarampat (2001), another important resource for Meranaw literature. Information on the themes, subjects, and contexts are vital contributions from Meranaw key informants.

Drawing upon the foregoing cited sources, the researcher then conducted a semiotic analysis of the significations of these pananaroons, guided mainly by the cultural semiotic perspective, and by other Meranaw texts which themselves provided the signposts and aided in determining the context and interpretations of the pananaroons, such as the Darangen. Finally, from the critical and probing analyses done, the researcher drew implications or revelations concerning Meranaw character, culture, and worldview.

\subsection{Locale}

The setting of the study is Lanao del Sur province's First District, where the sources of the samples are kept and the informants of the study are presently residing. Lanao del Sur is a province located in the Bangsamoro Autonomous Region in Muslim Mindanao (BARMM), and its capital is Marawi City. The most interesting topographical feature or landmark of the interior is the scenic Lanao Lake, the largest in Mindanao, and the center of livelihood and culture for the Meranaws. The lake has an area of 135 square miles and is shaped roughly like an isosceles triangle filling the depression of a collapsed plateau 2,300 feet above sea level. On its northern shores lies Marawi City, the capital of Lanao Del Sur. It is accessible by land, air or sea transportation from all points in Mindanao. Given this altitude, it is blessed with a mild climate, and thus remains comfortably cool throughout or at least for the better part of the year. Heavy annual rainfall keeps the Lanao landscape lush and verdant.

The setting for the study was selected, taking into consideration key informants residing in Marawi City. But it also considers the possibility that, through referral, other key informants from First District municipalities outside Marawi could also be considered, which is why the research setting cuts a larger swath, ranging over the Lanao del Sur First District itself. The choice of this setting is also because the researcher recognizes that the use of the pananaroon and its meanings are still common among Meranaws of every municipality, as the pananaroon is seen to be an oral tradition shared and understood by all native Meranaws. The Meranaws still consider it de riguier for their ceremonies the use of this literary art form. Therefore, the researcher sees fit for purposes of his inquiry to cover this entire part of the province. 


\subsection{Method of Data Gathering}

The researcher gathered data from both secondary and primary sources, described as follows:

1. Secondary Data. The secondary data are the initial data gathered, which are the pananaroons mostly from the work of Hadji Asis (1997) The Maranao Proverb: A Structural and Textual Analysis, from the work of Dimaporo (2016), Mranaw Perspective of Righteous Living Through an Analysis of Pananaroon, and from the Paninggalan sa Ranao by Macarampat (2001). The researcher deems these collections as having been collected from reputable authorities and scholars on the pananaroon, and thus can be safely presumed to have been properly scrutinized and verified before their inclusion, and have been frequently referenced by numerous other studies. The pananaroons that make up the study's corpus, thirty in all, were chosen and classified according to three contexts.

2. Primary Data. For the second phase of the data gathering, the researcher gathered information from the key informants of the study, to both enrich and ensure further authenticity and depth and richness of insight. The key informants were interviewed individually, but this was done online in view of the start of the implementation of the Enhanced Community Quarantine and lockdowns due to the then ongoing COVID-19 pandemic, which restricted mobility. Field work consisted in interviewing the six (6) key informants who are traditional leaders tapped for the study based on the inclusion criteria adopted for the purpose. Conformable with the established pertinent protocol, each was sent a formal letter inviting them to participate in the inquiry, and the interview protocol.

After securing the informed consent of the five (5) informants, the researcher sent them, online, the Interview Protocol, which already included carefully thought out follow-up questions. Each KI was given enough time (three weeks, or a month at most) to answer the guide questions. The questions were meant to verify the translation of each pananaroon, its interpretations, and the contexts in which these pananaroons, were deemed appropriate and useful, and upon which their meanings are dependent.

It must be noted that two (2) validators were asked to examine the data, especially its translations and contexts, for compilation as samples, before and after the data were enriched and authenticated by the key informants. The first validator checked the translations for accuracy or fidelity to the original Meranaw texts and the available interpretations for their sensitiveness or acuteness, before they were sent to the key informants. She, moreover, grouped or categorized the pananaroons according to context where these are most useful and apt, using propriacy or appropriateness as the determining criterion. After the samples' contexts and translations were authenticated, corrected, or supplemented by the key informants, they were then consolidated and validated again by the second validator, who also authenticated and added a distinguishing classification to the translations of the pananaroons, separating the literal and semantic translations of the pananaroons, as supplied by the texts and the key informants. Both the literal and semantic translations were utilized in the analyses of each pananaroon: the literal translations were used in identifying the signs occurring in each pananaroon, and the semantic translations, or a reconciliation of both the literal and figurative translations of the pananaroons, were also used to comprehend and analyze the signs' usage, and the pananaroon in general. For the consolidated list of the pananaroon samples and their translations, refer to Appendix A.

The validators were chosen for the following criteria: a) Is an English teacher; b) has adequate or expert knowledge on the Meranaw language and culture; and preferably c) has handled teaching subjects on the Meranaw language.

\subsection{Data Analysis}

For the study, the researcher employed the semiotic analysis approach and intertextual analysis on the sample pananaroons. Semiotic analysis for the purpose of this study drew on Barthes' (1991), Cassirer's (1923), and Posner's stress on cultural meanings, more particularly, the former's concept of connotations (formerly referred to as myths) which refer to symbols' ideological/cultural baggage or load.

Interpretation or determination of the meaning conveyed by the identified signs and the contextual background, and insights given by the key informants on these also involved intertextual analysis, as enunciated by Julia Kristeva who drew heavily on the formulations of Roland Barthes and Mikhail Bakhtin: the reference to, or dialogue of the texts under consideration with other Meranaw texts that may prove significant or illuminative in forming richer or more insightful interpretations. It must be noted, however, that the researcher committed himself to remaining faithful to the sample text and their original translations. This does not necessarily mean ignoring or discarding the key informants' comments or insights on the translations or previous interpretations made. The researcher is guided by the purpose and principle underlying triangulation: at a certain point, differing or divergent views somehow converge. 
Since the approach is primarily and fundamentally semiotic, the data analysis focused on the sign features of the pananaroon, especially the symbols, icons, and indexes incorporated in them, and their relation to the themes, interpretations, and contexts of their respective pananaroon. The linking of both, informed by cultural semiotic perspective, is pursuant to the study's ultimate end or purpose of revealing the Meranaw character, culture, and worldview.

\subsection{Pananaroon Samples}

The samples used for the study is provided in the following tables, classified according to their context:

\begin{tabular}{|c|c|c|}
\hline \multicolumn{3}{|c|}{ Courtship/ Marriage } \\
\hline $\begin{array}{l}\text { Pangiring iring a pong } \\
\text { si babendir a di moni }\end{array}$ & $\begin{array}{l}\text { The bass sound of a small gong } \\
\text { Cannot equal the high-pitched sound of a } \\
\text { bigger one }\end{array}$ & $\begin{array}{l}\text { What a pity, a small gong with a low- } \\
\text { pitched sound tries to imitate the high } \\
\text { pitched-sound of a big gong. }\end{array}$ \\
\hline $\begin{array}{l}\text { Ba ako mambo pandi } \\
\text { A o makaborod ko ig } \\
\text { Na ipagoman a bantog } \\
\text { O kalangowan iyo tanan. }\end{array}$ & $\begin{array}{l}\text { Am I a flag, } \\
\text { Which when flown in your place } \\
\text { Will add pride and dignity } \\
\text { To everybody? }\end{array}$ & $\begin{array}{l}\text { Am I a flag which when flown over the } \\
\text { water will add pride and dignity to every } \\
\text { one of you? }\end{array}$ \\
\hline $\begin{array}{l}\text { Ino pen di saeyaten } \\
\text { Imosala komokopor } \\
\text { A ino pen komokopor } \\
\text { Ka makababalebegen. }\end{array}$ & $\begin{array}{l}\text { Why not keep in open } \\
\text { The arrogant handkerchief? } \\
\text { It might be arrogant } \\
\text { Because it can really afford. }\end{array}$ & $\begin{array}{l}\text { Why not unfold the arrogant } \\
\text { handkerchief? It might really be arrogant } \\
\text { for it can afford to be so. }\end{array}$ \\
\hline $\begin{array}{l}\text { San bo sa minagirid } \\
\text { ko karodan a mawatan } \\
\text { na da sa minidayonan } \\
\text { ko ragat a pembataesen }\end{array}$ & $\begin{array}{l}\text { He is there off-shore } \\
\text { Looking at the faraway sea, } \\
\text { But not proceeding to sail } \\
\text { And cross the real sea. }\end{array}$ & $\begin{array}{l}\text { He is there off-shore } \\
\text { Looking at the faraway sea, } \\
\text { But not proceeding to sail } \\
\text { And cross the real sea. }\end{array}$ \\
\hline $\begin{array}{l}\text { Ino kon o di ako } \\
\text { Ko dowa repa binaning } \\
\text { Ay masowa aken } \\
\text { Ko sarepa mangondaya }\end{array}$ & $\begin{array}{l}\text { What will happen to me if I } \\
\text { Prefer a commoner wholely free } \\
\text { As better as a nobleman with } \\
\text { Restraints twice more than a commoner. }\end{array}$ & $\begin{array}{l}\text { What if I do not choose a two-fathom of } \\
\text { yellow? What will happen to me, if I go } \\
\text { instead for a fathom of free-born? }\end{array}$ \\
\hline
\end{tabular}




\begin{tabular}{|l|l|l|}
\hline Somasana so ikan & Confident is the Ikan \\
Ka tig iyan a rek iyan & That he owns what he had \\
So kalalangkoman iyan; & But this is not so; \\
Takinoba ka kena, & He is far from him as the sky, \\
Ka laod on so letingan. & Miles away like the sea. & $\begin{array}{l}\text { Confident is the lkan who thought he } \\
\text { owns what surrounds him; but it is not so, } \\
\text { for the sky is very far away. } \\
\text { Ilkan is a legendary fish-like creature. }\end{array}$ \\
\end{tabular}

\begin{tabular}{|c|c|c|}
\hline \multicolumn{3}{|c|}{ Kandatu/Leadership } \\
\hline Pananaroon & Translation & Literal Translation \\
\hline $\begin{array}{l}\text { Aya man a kandato na ibarat o kakhapal } \\
\text { a polayagan sa akal na kalakalat so geda. } \\
\text { Na panalongon so gagao na olinan so } \\
\text { kawarao. Na pagabakan so gani na } \\
\text { tardson so Iman. Tiyotopan o pirak so } \\
\text { kaiiisa o bansa na likban o pelata so } \\
\text { mona kanggiginawai. Na o tanto ka } \\
\text { Muslim na oba ka ki mabimban ko } \\
\text { ramayong a kakal ka di kaon bo ketanto. } \\
\text { Na Obaka ki mabiray ko gadong a di } \\
\text { lalayon ka di bo tanto kelanggay na } \\
\text { magaan bo komelas }\end{array}$ & $\begin{array}{l}\text { Leadership is like sailing a ship, which } \\
\text { requires wisdom and skill. There must be } \\
\text { kindness coupled with courage. Anger } \\
\text { should be tamed and faith must be } \\
\text { strengthened. It is not uncommon these } \\
\text { days that money has become powerful } \\
\text { than kinship and friendship, but if you are } \\
\text { a true Muslim, then do not be dissuaded } \\
\text { by money and worldly things for these } \\
\text { are temporary and will soon fade. }\end{array}$ & $\begin{array}{l}\text { For leadership, when compared to sailing, } \\
\text { has wisdom as its mainmast and instinct } \\
\text { its halyard. Mercy is its joist and courage } \\
\text { its steering wheel. Anger should be } \\
\text { tamed and faith must be strengthened, } \\
\text { for money has overcome unity and the } \\
\text { coin sealed off the brotherhood of the } \\
\text { past. And if you are a genuine Muslim, } \\
\text { then you shouldn't get distracted by the } \\
\text { colour purple, for you will not have it } \\
\text { forever. And then don't get lured by the } \\
\text { colour green for it won't last long. }\end{array}$ \\
\hline $\begin{array}{l}\text { Na o ba kalipati so taritib ago sempad ka } \\
\text { ayaden kasabapan a iphamagayao-ayao } \\
\text { sa kalodan sa Mindanao na perigayan so } \\
\text { palao sa da a tadem ko Laod na ipelabas } \\
\text { so orog so miaka mbalabala na o } \\
\text { migadong so sempad na kanogon o } \\
\text { phangampong } \\
\text { pephagampongon. }\end{array}$ & $\begin{array}{l}\text { We must not forget the laws and rules in } \\
\text { our culture, for its negligence may cause } \\
\text { chaos that may lead to the loss of our } \\
\text { motherland and its inhabitants. }\end{array}$ & $\begin{array}{l}\text { We must not forget cultural order and } \\
\text { laws, for its negligence will cause turmoil } \\
\text { on the sea of Mindanao while the } \\
\text { mountains seem indifferent to the sea, } \\
\text { and waves move loosely to and fro } \\
\text { everywhere; if the laws are forgotten } \\
\text { what will happen to our motherland and } \\
\text { her inhabitants. }\end{array}$ \\
\hline $\begin{array}{l}\text { O sa imanto aya na sarombakat so bagul } \\
\text { a dii makasonsanga ko kalodan o } \\
\text { selangan na o di phorongi mantang a } \\
\text { kisanggolay na lagi na pethimbangaros } \\
\text { so ig na phangenepan so ragat na } \\
\text { mataros a mabolos so panginam ko } \\
\text { donya na ayaden khasabapan sa } \\
\text { katarantana maog o pamoreg o bangnsa. } \\
\text { Na mapatola mabengkas so } \\
\text { kapenggiginawai na kanogon o } \\
\text { marandang a go so pephagingedon ka } \\
\text { aya khatamananon na sa di ron } \\
\text { makakendan na maka pendinganoman } \\
\text { ko oriayano kasendit }\end{array}$ & $\begin{array}{l}\text { We are now faced with various } \\
\text { challenges and opposing waves that } \\
\text { strike us from all directions. If we are not } \\
\text { careful and allow ourselves to be } \\
\text { drowned in worldly things, we might } \\
\text { sacrifice our kinship and love for each } \\
\text { other. Truly, conflicts will arise and we will } \\
\text { regret at the end. }\end{array}$ & $\begin{array}{l}\text { We are now faced with various } \\
\text { challenges and opposing waves that } \\
\text { strike us from all directions. If we are not } \\
\text { careful and allow ourselves to be } \\
\text { drowned in worldly things, we might } \\
\text { sacrifice our kinship and love for each } \\
\text { other. Truly, conflicts will arise and we will } \\
\text { regret at the end. }\end{array}$ \\
\hline $\begin{array}{l}\text { To ba lalan so korang na asar a } \\
\text { pimbitakan }\end{array}$ & $\begin{array}{l}\text { Even if we fall short of what is expected, } \\
\text { what is important is that we have done } \\
\text { our best. }\end{array}$ & $\begin{array}{l}\text { Even if we fall short of what is expected, } \\
\text { what is important is that we have done } \\
\text { our best. }\end{array}$ \\
\hline $\begin{array}{l}\mathrm{Na} \text { tomo den so kidalong a di so } \\
\text { kipamalata }\end{array}$ & Better to die than to lose one's honor. & $\begin{array}{l}\text { It is better to cover in shade than to be } \\
\text { disgraced in the open. }\end{array}$ \\
\hline $\begin{array}{l}\text { Saden sa mibasokan ka na aya ngka den } \\
\text { map'ragon. }\end{array}$ & What you sow is what you reap. & What you sow is what you reap. \\
\hline
\end{tabular}




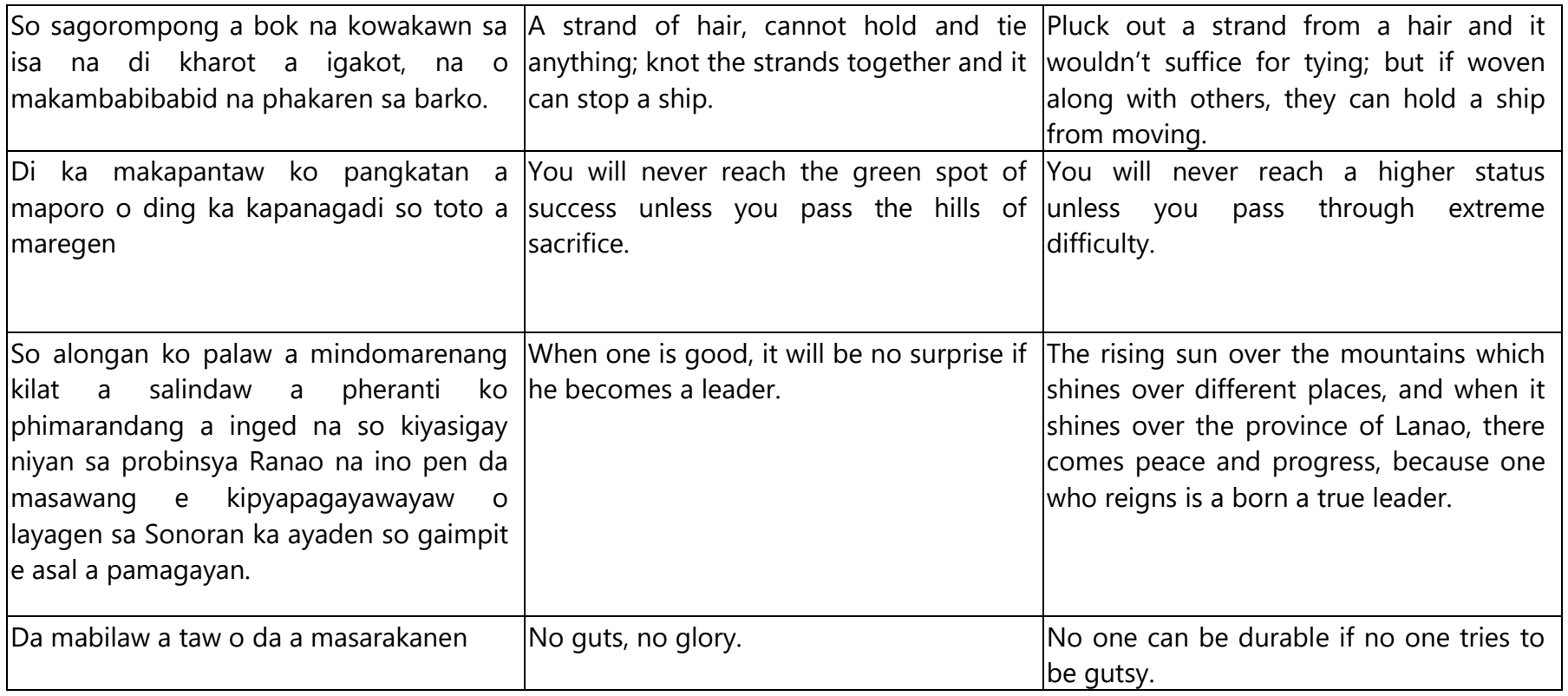

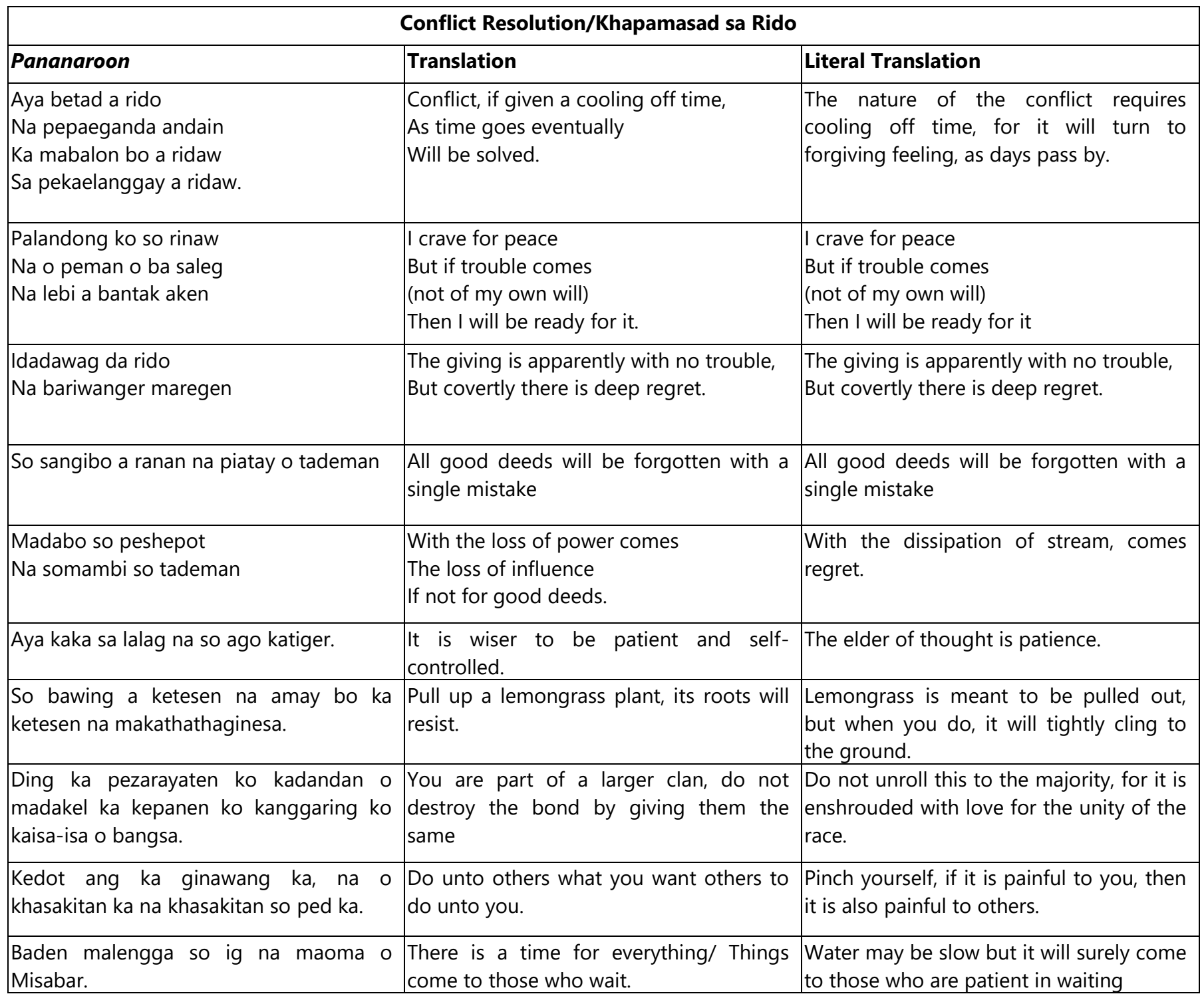




\section{Results and Discussion}

After a thorough analysis of the pananaroons, with focus on the cultural signs incorporated in them, the researcher found that the Meranaw pananaroon is indeed replete with signs that not only reveal the worldview and values of the Meranaws, but also show the nuances of these values that make them uniquely, culturally Meranaw. It is established in this study that the pananaroon are employed not only for rhetorical flourish or embellishment but for important purposes, namely: emphasis or heightening of effect; concreteness and vividness of a central message or point that the speaker seeks to drive home; for illustration; for indirection or subtlety to avoid causing offense and cushion the effect of the message (e.g. rejection), conformable to the ideal of kambilang a taw or refinement (gentilesse); for allusion to connect the present topic/theme to tradition or the past and endow it with authority or prestige; for self-deprecation or show of humility/self-effacement to gain advantage or some plus points. There are more specific uses like irony or expression of derision, contempt, or scorn (kapangilat), overstatement (hyperbole) and understatement, but these can be discussed under any of the identified major uses. Pananaroons, as stressed in previous studies, and by the key informants themselves, make very forceful or powerful clinchers and summing up devices. The variety of uses to which cultural signs are put shows to advantage the rich verbal possibilities of the Meranaw language.

Moreover, these signs are pregnant with what is enduring, significant, and persistent in Meranaw culture: age-old wisdom transmitted by their ancestors, concepts, and core values. Belonging to the first or highest order are those having to do with, or making up, the Meranaw world view: the realization of the evanescence or impermanence of all worldly things specifically power and wealth; the importance of valuing the akhira over the dunya; belief in a cosmic unity (unity of the Sacred, Nature, and humanity's social life) as reflected in unity among individuals, families, clans, and the bangsa and the social hierarchy which neatly divides or classifies men into the pegawidan and the pegawid (on which depends one's place or role in society); belief in order by faithful adherence to the taritib ago ijma (a set of laws, principles, and procedures comprising a Code or Charter laid down by their ancestors); belief in divine justice or cosmic balance (balance), commonly known as karma, murka, or tiyoba (whatever ye sow, ye shall reap); and the Golden Rule.

As vividly illuminated in the pananaroons are the richness, uniqueness and intricacies of Meranaw culture: the high valuation of maratabat (honor); the emphasis on certain ideals or standards summed up in such concepts as anonen a rawaten and kambilang a taw (gentility or the Meranaw version of gentilesse) and related values, specifically kasanggila or kapangali, and refinement and elegance of manners; still related to kambilang a taw and anonen a rawaten is respect for traditions and customs established by their ancestors, as demonstrated in courtship and marriage, selection of a leader (sultan, radiamuda or cabugatan), and conflict resolution/settlement; belief in kapagisa-isa kapamagawida, and kathotonganaya, and the importance of the interest of the clan or the group over personal interest, reciprocity, and mutuality; and pride in their bangsa, lineage or descent. There are also objects or signs by which they are identified - e.g. gong or agong, pandi, mosala, benaning, etc.

The Meranaw character shines through the pananaroon: prudence, humility, patience, perseverance and industry, family values; daring or boldness and bravery; self-restraint or discipline; fear of the Incommensurable or Supreme Being and divine retribution; deep sense of responsibility and awareness of his role in the society; respect for tradition or the ways of the ancestors (taritib ago ijma); appreciation of refinement and elegance and disdain for the vulgar, offensive, or indecorous; sensitivity to the feelings of others; and love of peace, order, and harmony. All of these are conveyed by brief or pithy, but artfully stated proverbs, meant to evoke images and concepts that are richly redolent of Meranaw culture, and character, home, and life, to better impart the messages they contain.

The pananaroons' enduring purpose and significance was confirmed in the study. They were confirmed by the informants as being still actively used as wise sayings or witticisms, expressions of general appeal, references, and words of wisdom, as Hadji Asis (1993) described them in her study. Their utility is manifest in many situations or festivities in which traditional leaders and influential speakers in the community are invited to join and speak. They are indispensable to the ongangen or one trained in public speaking (oratory) who are usually tapped as spokespersons for a family/clan, party or organization. The informants could hardly find an important occasion in which pananaroons do not come handy, from traditional, cultural events such as kakawing (marriage), kandatu (enthronement), and khapamasad sa rido (conflict resolution), to other communal celebrations, even government programs, religious congregations, and academic events. This is shown in the variety or wide range of the contexts, interpretations, and translations in which one pananaroon may be found appropriate, as related by the informants, and how this applies to all: one pananaroon may be specifically made with a particular situation in mind, but may also be apt or fitting for, or in, other situations, from the most important of events, wherein katharo sa lalag is necessary, to everyday conversations and sage advices by an elder towards the younger generation. As such, the pananaroons have endured through and over time, kept alive and vital by the speakers that are steeped in tradition and well-versed about Meranaw rhetoric. 
The signs incorporated in these pananaroons, specifically regarded in the study as cultural signs, are critical to meaning-making or conveying the message. Whether they are in the form of mere words, symbols, or images, the signs are clearly cultural for they were analyzed here as reflecting the worldview, environment, and lifestyle of Meranaws. There was a prevalence of signs common in the natural environment like water (ig), the Ranao, and the sea (ragat, kalodan). There were also some signs for certain activities such as sailing (phapalayagan, layagan), and farming (pembasok) which Meranaws usually engage in as a means of living. The Meranaws, being sailors/mariners, fishermen, and farmers, and even drawing their ethnic identity from the Ranao itself, it is not difficult to see why these natural signs/images from their environment were used as signs in their pananaroons, a phenomenon Eugenio (1987) also confirms as a normal occurrence in proverbs. Other natural signs that were also used include the sun (alongan), mountains (palaw, pangkatan a maporo), letingan, or sky; map-ragon (harvest); waka, a fibrous plant, the bawing (lemongrass); ikan (bird); lansa, barko and even mata (eyes) and bok (hair).

Traditional items, objects, even colors were also made use of as signs: items such as the mosala, or handkerchief, pandi or flag, and the babendir or gong; colors, such as binaning, or yellow, gadong or green, and rambayong or purple. Other common signs used include allusions or references to the Darangen (Gandamato Damedag), references to acts and practices that Meranaws engage in such as farming, sailing, courting a lady, giving of gifts, becoming a leader, etc. There are also references to emotions and abstract concepts such as desire and anger, peace and war, leadership, love, family, and social class. These abstract concepts are made concrete through images, analogies or metaphors and other figures of speech.

Though much of these concepts may be considered as existing in many other cultures and societies in some similar form, they are considered significations of the culture and worldview of the Meranaws, because of their treatment in these pananaroons as cultural signs. Just as Cassirer (1923) stated, sign systems are studied with respect to what they contribute to the culture, and the advantages and disadvantages which an individual experiences in belonging to a specific culture. The pananaroons, sign systems themselves, contribute to our knowledge of the Meranaw culture and the individual Meranaw through its unique treatment of these universal concepts and symbols, thus making them vividly evocative or redolent of their origin as natural signs, and distinct from their treatment in other cultures and societies. The message may have a transcultural or universal dimension, but the way they are constructed or crystallized is culture-specific, that is, recognizably and distinctively Meranaw.

In the study, the use of these common signs offers a broader view of the Meranaw perspective, such as the references to environment/natural signs: the sun, alongan, symbolizing power, rule, and plenty or abundance; the Lake (Ranao) and the sea (ragat), which occur repeatedly like leitmotifs, in many pananaroons, and are treated as symbols of life on the one hand, and on the other, as symbols of difficulties (using turbulent waves), mainly of unpredictable aspects of Meranaw life (marriage, adulthood, quest for certain goals), the mountains (palaw) and sky (letingan) as symbols of success and successful scaling of the heights, the use of the characteristics of the waka and bawing plants to describe weak-willed and arrogant people, respectively, and the imagery of hair and eyes as symbols to uphold the Meranaws' high regard for unity, and as a nuanced look into the difficulty of expressing desire and love in the Meranaw society.

Traditional or cultural objects and colors serve as signs, that is, as indices or symbols: from the use of the mosala or handkerchief, the reader knows that the pananaroon deals with the authority, ability, and potency associated by the Meranaws with one possessing it (vestimentary semiotics, or by one's accoutrement one is known); the pandi which is the equivalent of a totem in primitive societies or /standards /emblems/ insignias in other cultures' heraldry is described as raised or planted when the pananaroon speaks of the Meranaws' concepts of pride and merrymaking, and the beating or sound of the gong and babendir in a Meranaw society signifies the ultimate authority or power of the Sultan (or datu) who alone has the power to issue and announce royal edicts. The color binaning is, to a Meranaw, not just the color yellow; it is the symbol of gold, of nobility, and it makes pananaroons containing it easily recognizable as dealing with the aristocracy or the ruling class; gadong, or green, means treasure, and in a pananaroon, its use is as a symbol or synecdoche for all the treasures of the world, but is considered transient or fading in comparison to everything in the afterlife (akhirah) which is eternal, highlighting the importance of that Islamic concept, and Islam itself, to Meranaw life.

Other signs are references, again, to acts and abstract concepts, used to dwell on these concepts and impart wisdom to the younger generations: the reference to Gandamato Damedag in one pananaroon becomes an invitation to revisit the andang a meona or ideals by which the ancestors steered or lived by, as depicted in the Darangen, specifically the Kaplomna which describes in detail, and preserves, the idealized view of noble courtship. The pananaroons that deal with acts such as giving a gift, offending a peer, courting a lady and her family, finding peace, and leading a nation, serve to explain how these situations, in a way didactically, work in a Meranaw society. From the simple act of farming, Meranaws drew a pananaroon that speaks of perseverance, proactivity and of daring to go further; from giving a gift and offending a peer in any way, the Meranaws drew 
succinct pananaroons that reveal how a seemingly insignificant act may lead to a rift or ridu that may take decades of bloodbath to settle or end, giving insight into the sensibilities so zealously guarded to the Meranaws. One pananaroon on leadership spoke of all the characteristics a leader must possess to become an effective leader, and it revealed much about the expectations for a Sultan or head of a family, perhaps even a Meranaw in general; exalting blood and family ties, putting the afterlife and Islam over worldly pleasures, and attacking the poison or social and spiritual decay that is inflicted by worship of money on the Meranaws' way of life.

In summary, the study found that these pananaroons, though generally short or terse, and seemingly focusing on one insignificant or singular aspect or concept of Meranaw society and character, one symbol, one image, were able to paint a vivid, nuanced picture of said society, because Meranaws rely on these to relay the cultural and societal complexity, richness, uniqueness and depth of the Meranaw culture. Specific situations or aspects of their culture are explained through the pananaroons: for example, Meranaws find courtship as an endeavor necessary for the completion of an individual's life, an unknown sea to sail, and a long process that will require no small amount of fortitude, daring, proactivity, wealth; marriage, the consummation devoutly wished, serves not only the purpose or wish of the couple, but ultimately, the prestige, respect, and bonds between families. Leadership, to them, is to have complete authority, influence, and power, one that is divinely sanctioned, yet through the pananaroons is also shown what the loss of such authority could mean, and the sheer weight of such a position; the steering of the Meranaw bangsa through a tumultuous period where money and materialism has overtaken what are, to the Meranaws, the penultimate values that are the foundations upon which the nation is built on: unity (kapagisa-isa), collectivism (kapamagawida, kathotonganaya and kaproroyoda), and strong ties based on blood, family/clan and friendship; Islam, and the values it preaches; and the unspoken but deeply held laws (taritib ago igma) that govern it. Peace is seen to hinge on mutual respect, reciprocity, carefully thought out acts that Meranaws must hold up individually (bilanggatao or bilantadi), and conflict is a concept Meranaws try their utmost to avoid, but one that they would not shirk or run away from when it comes unbidden. However, even conflict (ridu) breaks out, the Meranaw's ultimate wish is to find peace through sincere effort to settle or resolve it, though they believe that the desired resolution may only be brought by time.

From the analysis, we also draw the general, foundational ideals and worldview that Meranaws as a people value in all things, regardless of context and situation: patience, prudence; deliberation seems to be embedded and encouraged in all their doings, in all situations. Acting or deciding on impulse is avoided as it might offend or incur the displeasure of the Other. They also believe that some calculated boldness and daring, and going through arduous journeys, are still what bring success, and that procrastination or vacillation is a fault, whether in courtship and marriage, leadership, war, or trade. It is also revealed that there is room and forgiveness for failure, for falling short of one's expectations, whether as a noble, a leader, or a commoner. Meranaws as a people, as gleaned from the pananaroons wish for clearness, harmony, order and peace (rinaw) in all things; they wait for socalled auguries or favorable auspices before they act, they prefer calm or self-possession to succumbing to anger, and they desire only peace among themselves and their community, above all. in many of the pananaroons, Meranaws extol humility and the awareness of one's station over excessive confidence, which is indicted in other pananaroons as arrogance. Ingrained in, or internalization by the Meranaw is the class system, the trappings associated with it, and how it determines a Meranaw's future, choices, and aspirations, and guides or governs his behavior. Dishonor, to them, is worse than death, and one offense may sour a couple's marriage, or turn good relations between two families into a bitter feud. In Meranaw society, although relationships are highly valued, these must be acknowledged as very fragile or delicate like glass. Thus utmost care and sensitivity must be observed to avoid driving a wedge into, and ruining relationships.

\section{Conclusion}

Quarried for cultural signs and their meanings, through semiotic analysis and intertextual analysis, the Meranaw pananaroons have proved to be effective and rich vehicles of the enduring, significant, and cherished in Meranaw culture - their worldview or system of beliefs and values, their life ways, and their character. It is a marvel considering the pithy or terse form into which these truths are compressed. However, as the analyses revealed, economy of means or condensation is achieved through cultural signs (Cassirer) consisting of myths or connotations (Barthes), icons, indices and symbols, and signs giving shape to interpretants and further interpretants (Peirce), and images and allusions (Kristeva).

From the study, cultural values that are distinctively or uniquely Meranaw are illuminated. Also brought to light are values that may be considered "universal" or transcultural, such as the Golden Rule, belief in justice, peace, and the evanescence or ephemerality of worldly existence and goods. The Meranaw worldview can be drawn from these remarkably brief and condensed sayings: in every situation, every choice, every act, every word spoken, even thoughts or harbored resentment, bear with them ramifications that affect the entire clan or community. The Meranaw does not, and cannot, act for himself or herself, for each individual is part of the main -- a collectivity larger than an individual; the achievement, successes or goodness of one uplift not 
only oneself, for example, but his entire clan (bangsa), or his/her community. As such, there is a vital equilibrium that they must keep inviolate, an equilibrium between individuals, families, clans, and communities, of their social and governmental structure. This balance must be preserved. From the pananaroons, it is implied that to them, it could take only a single mistake to disturb the equilibrium, ruin the established order and harmony, ruin relationships, sever ties, and tear their land apart. As such, they approach endeavors, challenges or problems in life courageously but cautiously, combining boldness or daring and prudence, patience and perseverance. The Meranaw, zealously protective of his maratabat and, at the same time, sensitive to the sensibilities and of the Other, shuns impetuosity or acting on impulse; he is understandably calculating and deliberate.

There is no one answer to a conflict, an obstacle, no extreme right or wrong; acts must be appropriate to the situation. This attitude, summed up in the ideal of kambilang a taw, is ingrained in the Meranaw, almost from birth, through early training. A Meranaw must dare to do and aspire more to achieve success, but must also be considerate of the people around them, and as such, must be flexible and careful in their decisions. For there are two things that are revealed to be what they assuredly value above anything; Allah (swt) and the promise of the hereafter, and the balance, peace and order of the Meranaw bangsa. Meranaws must prove themselves worthy of their noble descent or lineage which they trace to their ancestors, the mythical heroes of Rajah Indarapatra and the Darangen. These revered ancestors laid down paradigmatic models or patterns - rules, procedures and the like - that are enshrined in the taritib. Everything of consequence that they do, for example, making a marriage proposal, selecting a leader, and negotiating a conflict settlement, must be referred to the taritib.

The pananaroons and its signs are thus a rich mine of information about how the Meranaws live their lives, the principles and values by which they steer, giving order, coherence, and direction, and meaning to their lives. They confirm that, to Meranaws, all things bear cultural complexity, weight, and meaning, be it a natural sign/phenomenon (calm or turbulent sea), verbal sign (ilat or innuendo, word of self-deprecation intended as irony), gestural sign (done with the mosala), symbol (raised pandi) or a simple procedure which, in the first place, is why they were able to resourcefully formulate pananaroons from the most obscure of plants, or the mundane task of farming or sowing, or the sound of the babendir contrasting with that of the gong, to explain the most important, most complex of their values and perspective. By doing so, by turning cultural signs unique to the Meranaw culture into these sayings, they are able to convey messages and wisdom that are instantly comprehensible to those of their own culture. Aremu (2015) has astutely pointed out that proverbs are "a powerful medium to hold and transmit from generation to generation the culture, philosophy, social morality, values, and sensibility of a people". This is what accounts for the vibrant life of the Meranaw pananaroon even today, amid prodigious change and powerful forces like modernization and the incursion Bachit as the medium by which the significant and enduring of Meranaw culture is preserved. As long as these signs - words, symbols, situations, and acts -- are still alive, still held as true, so will the pananaroons live, persist and endure, and vice versa.

The researcher recognizes that the results or methodologies of this study could open up new avenues or paths for fresh inquiry on Meranaw pananaroon in particular and Meranaw folklore and culture in general. Yet, due to constraints or limitations on time, resources, and mobility, limited and hampered in large part by the ensuing COVID-19 pandemic, he had to settle for pananaroons that were selected from available secondary sources. He believes that more persistent tillings or search might yield more samples and variants of what already have been collected. As such, the first recommendation advanced by this researcher for future researchers is that field work of the ethnographic kind be conducted without let up. Researchers can try collecting fresh samples from authoritative primary sources, preferably aged 70 or older, who represent the older generations.

The researcher also recognizes that there is a scarcity of cross-cultural studies of proverbs. The researcher recommends that other researchers undertake such studies to discover variants and "universals". Such studies can be broadly grouped into two: a) "cross-cultural" used in a narrower sense and encompassing only the art of the pananaroon among the different indigenous groups in Mindanao in particular, and the Philippines, in general, and b) "cross-cultural" used in a broader sense and encompassing cultures of other countries, particularly neighboring countries in Southeast Asia or the Western Pacific, and those making up Central Asia. Another recommendation the researcher thinks is worth looking into is a study focused on translation problems. As observed by the researcher, there were instances when the interpretations of the informants somewhat differed; this may be due to varying translations. So far, there is no known serious work on this problem in relation to the art of the pananaroon. Future studies using the same or a new approach on other corpora or collection of pananaroon, focusing on more specific aspects of the pananaroon, such as thematic or contextual similarities, should be as fruitful and engaging. This can be a step toward systematically developing pananaroon typologies. 
Funding: This research received no external funding.

Acknowledgments : All resolve and efforts would have been in vain without the support and encouragement of many people and institutions: the Mindanao State University, which provided a challenging and supportive learning environment that inculcated in me my skills, knowledge, values and interests; Dr. Hasmina D. Sarip-Macarambon, this research's adviser and coauthor, for her untiring guidance at the different stages of this work, encouragement and reminders, patience and valuable suggestions, and the study's name; Dr. Rebekah M. Alawi, this research's editor and the researcher's grandmother, for her inspiring interest in the project (which, in fact, found its genesis from her own suggestions), her guidance and helpful tips, editing and proofreading, and lending this research the bulk of its sources - books, theses and dissertations - from her private library. Camid Alawi, the researcher's grandfather, for his support and his valuable input; Shakira and Sohaily Bantog, the researcher's parents, for their constant reminders and indefatigable efforts in providing suggestions, sources, and connections to my informants during, before, and after the data gathering period; Dr. Grace Rafal, Sir Mosa'ab Mangurun, and Prof. Rocaira Gumal, this research's faculty panel members and validators, for their professional guidance, warmly offered corrections, and invaluable insights; the esteemed Sir Abdul Hamidullah Atar, Sir Salih Macabero, Dr. Dayang P. Ali, Dr. Anisah Ahsanonnisah Muti-Pangcatan, and Ma'am Morsidah D. Dadayan, honored Meranaw traditional leaders and this study's key informants, whose expertise, insights, and perspectives, were invaluable and the crux of the efforts to truly understand the depth that the Meranaw pananaroon, culture, and worldview possess; the English Department Faculty as venerable mentors who also offered key suggestions for this study; the English Majors' Society, the Melons, ISED Batch 2015, family, and friends, for their uplifting, unending support and camaraderie.

Conflicts of Interest : The authors declare no conflict of interest.

\section{References}

[1] Abrams, M. H. (1968). The Norton anthology of English literature. W.W. Norton.

[2] Aremu, M. A. (2015). Proverbs as cultural semiotics in Soyinka's Death and the King's Horseman. The Journal of Pan African Studies. 8-5. 115125.

[3] Ananggo, M. L. (2000). The proverbs of Ramain: their cultural values, images, and symbols. Masteral Thesis. Mindanao State University.

[4] Akbarian, I. (2010, Spring). A spice of classroom: incorporating proverbial expressions in EFL classes. Journal of Asia TEFL. 7(1). 221-238.

[5] Akporobaro, F., \& Emovon, J. A. (1991). Nigerian proverbs: meanings and relevance today. Jeromelaiho and Associates.

[6] Alangca-Azis, J. The Meranaw View on the Language of Ridu Negotiation. Dissertation. Mindanao State University.

[7] Bailey, G. \& Peoples, J. (1999). Introduction to cultural anthropology. Thomson Wadsworth.

[8] Barthes, R. (1975). Roland Barthes par Roland Barthes. Editions de Seuil.

[9] Barthes, R. (1991). Mythologies: Roland Barthes. Hill and Wang.

[10] Berger, A. (2004). Media analysis techniques (3 $3^{\text {rd }}$ ed). Sage.

[11] Bogatyrëv, P. (1971). The functions of folk costume in Moravian Slovakia. Mouton.

[12] Bolinger, D. (1980). Language - the loaded weapon: The use and abuse of language today. Longman.

[13] Cali, H. L., Coronel, M. D. (1986). Darangen: In original Maranao verse with English translation. Mindanao State University.

[14] Cassirer, Ernst A. (1923). The Philosophy of Symbolic Forms. New Haven CT.1953-57.

[15] Cimene, F.T., Cabrillos, F.M., Santander, M.E. (2019). Language and Maratabat: A Potential Source of Ethnic Conflict. Retrieved November 2, 2019 from https:// www.researchgate.net/publication/331968155

[16] Cuddon, J. A. (1984). A dictionary of literary terms. Penguin Books.

[17] Curo, N., (2008). The Euphemistic Expressions in Meranao Ceremonial Speeches: Their Meanings and Implications. Undergraduate Thesis. Mindanao State University.

[18] Danesi, M. (2004). Messages, signs, and meanings: a basic textbook in semiotics and communication. Toronto: Canadian Scholars' Press Inc.

[19] Daramola, A. (2013). A semiotics of aspects of English and Yoruba proverbs. The Journal of International Social Research. 6-24. 99-108.

[20] Dimaporo, N. (2016). Mranaw Perspective of Righteous Living Through an Analysis of Pananaroon. Undergraduate Thesis, Mindanao State University.

[21] Dipatuan, N. \& Sangcopan, N. (2012). Simple Pananaroon for Meranao ladies: level of understanding and its relevance to new Meranao generation. Undergraduate Thesis. Mindanao State University.

[22] Disoma, E. (1999). The Meranao (a study of their practices and beliefs). Graduate Thesis.

[23] Eugenio, D. (1987). Philippine Folk Literature: An Anthology. Philippine Folk Literature Series, Vol. I. Diliman, Quezon City: Folklore Studies Program, College of Arts \& Sciences, University of the Philippines, and The U.P. Folklorists, Inc.

[24] Esimaje, A., Masagbor, R. A., Ezirim, C. D. (2014). Proverbs as Iconic and Indexical Markers of Culture: Exploration of the Proverbs of Four Nigerian Cultures. An African Journal of New Writing. 51. 253-269.

[25] Fardejah, K. (2017). Chapter 3: early Philippine civilization and its Asian influences. Retrieved October 21, 2019 from http://students.aiperez.

[26] Francisco, J. (1995). Sarimanok and the Torogan: \& other essays. Mindanao Journal. 21. 1-2.

[27] Goling-Pantao, A. (2018), Meranaw ideology as reflected in kakawing speeches: a critical discourse analysis. Dissertation. Mindanao State University

[28] Guessabi, F. (2017) Blurring the line between language and culture. Language magazine. Retrieved January, 18 October from https://www.languagemagazine.com

[29] Grzybek, P. (2014). Semiotic and semantic aspects of the proverb. Retrieved October 21, 2019 from www.semanticsscholar.org.

[30] Guro, N. (2008). Meranao Ceremonial Speeches: Their Meanings and Implications. Undergraduate Thesis, Mindanao State University. 
[31] Hadji Asis, R. (1997). The Maranao proverb: A structural and textual analysis. Minadanao Art and Culture. Mindanao State University.

[32] Hooft, S. (2009). Cosmopolitanism: a philosophy for global ethics. Cambridge University Press.

[33] Kristeva, J. (1980). Word, dialogue and novel. In L. S. Roudiez (Ed.), Desire in Language: A Semiotic Approach to Literature and Art (pp. 6491). New York, NY: Colombia University Press. Literal translation. Longman Dictionary of Contemporary English. Retrieved September 1 , 2019 from https://www.ldoceonline.com/dictionary/literal-translation

[34] Lanao del Sur. PhilAtlas. Retrieved October 21, 2019 from www.philatlas.com

[35] Lobel, J.W., Riwarung, L.H.S. (2009). Maranao: a preliminary phonological sketch with supporting audio. Language Documentation \& Conservation. 5. 31-59.

[36] Macaraya, B. (1993). Lexicon of classical literary Maranao words and phrases. MSU Research Center.

[37] Madale, A.T. (1966). A preliminary study of Maranao folk literature. Institute for Research for Filipino Culture.

[38] McKaughan, H. \& Macaraya, B. (1966). A maranao dictionary. De La Salle University Press, Inc.

[39] Mieder, W. (2004). Proverbs: a handbook. Greenwood Folklore Handbooks. Greenwood Press.

[40] Macarampat, J. (2001). Paninggalan sa Ranao. Mindanao State University.

[41] Peirce, C. (1931). Collected Papers. Harvard UP.

[42] Posner, R. (2004). Basic tasks of cultural semiotics. Signs of Power - Power of Signs. Essays in Honor of Jeff Bernard. INST. 56-89.

[43] Reyes, M.E. (2012), Abdulmalic, N.M., Matanog, I. I. Maranao women as portrayed in selected Maranao folktales. Advancing Literature \& Communication Research. 1. 43-61.

[44] Rezaei, A. (2012). Rhetorical function of proverbs based on literary genre. Procedia - Social and Behavioral Sciences. 47.1103 - 1108

[45] Saber, M., \& Madale, A. T. (1975). The Maranao. Solidaridad Pub. House.

[46] Sarangani, P. (2010). The Meranao bayok and popular songs: stylistic and thematic analyses. Undergraduate Thesis. Mindanao State University.

[47] Sarip, H. D. (2018). Meranaw Rina-Rinaw: its language and structure. Journal of Education and Social Sciences. 10-1. 159-173.

[48] Sharief, A. (2008). The Maranao kandaonga as ritual speech and verbal art. Undergraduate Thesis. Mindanao State University.

[49] Taylor, A. (1931). The proverb. Harvard University Press

[50] Taylor, A. (1950). Ritual Magic. Speculum.

[51] Ulla, M.B. (2014). Meranao folksongs: a revelation of the behavioral patterns, culture and practices. European Journal of Academic Essays. 1 4. 57-61.

[52] Umar, A. (2017). A socio-semiotic analysis of gender relations in Hausa proverbs. Journal of Cognitive Science. 18-3. 237-254.

[53] Velasco, E. (2017). Maranao folksongs: their dominant themes and implications to Maranao culture and identity. International Conference on Arts, Literature, Humanities and Social Sciences. 134-137. 